\title{
PELATIHAN PENERAPAN PEMBELAJARAN "PAIKEM" \\ BAGI GURU SEKOLAH DASAR MUHAMMADIYAH \\ DI DESA RANDU, KEC. SUBAH, KAB. BATANG TAHUN 2010
}

\author{
Zaenal Abidin \\ Jurusan Tarbiyah - Fakultas Agama Islam \\ Universitas Muhammadiyah Surakarta
}

\begin{abstract}
Learning is an urgent issue in educating nations, to build natonal character, and to set up the noble moral. This clearly defined in the function and the objective of national education, that the national education functioned to develop the ability, to build character, and to raise the value of national civilization in order to brighten national life. Its goal is to develop the potential of the student in order to be a faithful and pious person toward God the One, to have the good moral, to be healthy, learned, be capable, creative, autonomous, and to become a democrative and responsible citizen.

Desa Randu, Kecamatan Subah is the supportive area in Kabupaten Batang. Desa Randu is one of the Branch of Muhammadiyah which quite progressive in Kecamatan Subah, but most of the school development in Kecamatan Subah not welldeveloped yet.

In order to fulfill the need, so it necessary to held a training and teaching practices in Microteaching that conditioned as the active learning to the teacher especially the private teachers (Muhammadiyah) with the materials designed by and for the teacher in Teaching and Learning Process.

The method used to realizationing this program is in form of training to design PAIKEM Learning (Active, innovative, creative, effective, and exciting) for teacher in SMP Darul Hijrah Desa Randu, Kecamatan Subah Kabupaten Batang.

After training, the teacher feel the benefit of participative learning model also they feel happy about the training.
\end{abstract}

Kata kunci: pembelajaran,PAIKEM

\section{PENDAHULUAN}

\section{Analisis Situasi}

Dunia pendidikan merupakan salah satu pranata yang terlibat langsung dalam mempersiapkan masa depan umat manusia. Kegagalan dunia pendidikan dalam meyiapkan masa depan umat manusia adalah merupakan kegagalan bagi kelangsungan kehidupan bangsa (Nata, 2003: 159-160).

Problem yang dihadapi manusia di zaman modern adalah menghendaki visi dan orientasi pendidikan yang tidak semata-mata menekankan pada pengisian otak, tetapi pengisian jiwa, pembinaan akhlak dan 
kepatuhan dalam menjalankan ibadah. Dunia pendidikan merupakan salah satu pranata yang terlibat langsung dalam mempersiapkan masa depan umat manusia. Kegagalan dunia pendidikan dalam menyiapkan masa depan umat manusia adalah merupakan kegagalan bagi kelangsungan kehidupan bangsa (Nata, 2003: 159-160).

Peningkatakan mutu pendidikan dari tahun ke tahun selalu diupayakan, baik pendidikan pada tingkat dasar, menengah maupun pendidikan di perguruan tinggi. Pembenahan itu dilaksanakan di segala bidang antara lain; sarana/fasilitas, kurikulum, pendidik atau guru. Perubahan kurikulum beberapa kali dilakukan, dan perubahan ini memberikan dampak besar bagi proses pembelajaran yang sedang berlangsung.

Pendidikan secara kultural pada umumnya berada dalam lingkup, peran, fungsi dan tujuan yang sama. Semuanya hidup dalam upaya mengangkat dan menegakkan martabat manusia melalui transmisi yang dimilikinya. Terutama dalam bentuk transfer of knowledge dan transfer of value (Hasbullah, 1996: 5).

Pembelajaran adalah masalah urgen dalam mencerdaskan bangsa, membangun karakter bangsa, membentuk akhlak karimah. Hal ini tergambar dalam fungsi dan tujuan pendidikan nasional, yaitu bahwa pendidikan nasional berfungsi mengembangkan kemampuan dan membentuk watak serta peradaban bangsa yang bermartabat dalam rangka mencerdaskan kehidupan bangsa, bertujuan untuk berkembangnya potensi peserta didik agar menjadi manusia yang beriman dan bertakwa kepada Tuhan Yang Maha Esa, serta berakhlak mulia, sehat, berilmu, cakap, kreatif, mandiri dan menjadi warga negara yang demokratis serta bertanggung jawab (UU Sisdiknas; 2003: 6 - 7). Berdasarkan uraian tersebut dapat dikatakan bahwa pembelajaran itu penting karena sebagai wahana menyiapkan generasi yang berkualitas.
Untuk itu pelaksanaan pembelajaran hendaknya dibedakan pada tiap-tiap jenjang pendidikan. Perbedaan tersebut dengan mempertimbangkan usia perkembangan mental, dan intelektual. Kebijaksanaan dalam perbedaan perlakuan tersebut jelas berpengaruh terhadap cara berfikir maupun dalam bersikap.

Dunia pendidikan menuntut manusia untuk berubah dan merubah. Teori pendidikan dan pelaksanaan kegiatan pembelajaran membuktikan bahwa guru harus mengubah paradigma pengajaran lama. Pelaksanaan pendidikan perlu menyusun dan melaksanakan pembelajaran pada pemikiran baru atau pemikiran alternatif dimana kegiatan pendidikan adalah suatu proses sosial yang tidak dapat terjadi tanpa interaksi antar pribadi. Belajar adalah suatu proses pribadi, dan juga proses sosial ketika masing-masing orang berhubungan dengan yang lain dan membangun pengertian dan pengetahuan bersama (Johnson, Johnson dan Smith dalam Anita Lie, 2002: 6). Pada dasarnya proses pendidikan adalah seiring dengan proses kehidupan. Hal ini dikuatkan oleh pendapat Riberu yang mengatakan bahwa pengetahuan dan teori tentang bagaimana berlari yang baik tentu saja akan menambah pemahaman seseorang tentang hal ihwal berlari. Akan tetapi teori-teori tersebut tidak dapat membuat ia menjadi pelari yang baik apabila ia mencukupkan diri dengan teori itu saja, untuk mencapai hasil yang optimal, ia harus mendapatkan kesempatan guna mengaplikasikan teori-teori tersebut dan berlatih berlari tahap demi tahap dengan perbaikan seperlunya. Hal yang sama juga berlaku untuk pembelajaran yang lain, seperti kemampuan berfikir, keterampilan bergaul dan manajemen (Rooijakker, 1986: xxi).

Masyarakat, sekolah dan nilai adalah tiga faktor penting yang tak terpisahkan dalam pelangsungan regenerasi. Ketiga faktor tersebut tergambar dalam UU Nomor 
25 tahun 2000 tentang program pembangunan nasional (PROPENAS), dinyatakan bahwa ada tiga tantangan besar dalam pendidikan di Indonesia yaitu 1) mempertahankan hasil pembangunan pendidikan yang telah tercapai, 2) mempersiapkan sumber daya yang kompeten dan mampu bersaing di pasar global, 3) sejalan diberlakukannya otonomi daerah, sistem pendidikan nasional dituntut untuk melakukan perubahan dan penyesuaian sehingga dapat mewujudkan proses pendidikan yang lebih demokratis, memperhatikan keberagaman, memperhati-kan kebutuhan daerah dan peserta didik, serta mendorong peningkatan partisipasi masyarakat (Hasbullah, 2007: 1).

Sebagai guru profesional sebelum mengadakan pembelajaran tentunya telah mempersiapkan pembelajaran secara strategis agar dapat menumbuhkan motivasi dan lebih memahamkan siswa secara sederhana dalam komunikasi pembelajaran. Untuk membentuk kesan siswa yang kuat dan bermanfaat perlu mempertimbangkan hal-hal penting di atas dalam memilih dan menentukan strategi.

Dewasa ini, banyak orang tua yang bingung dengan cara guru melaksanakan pembelajaran di sekolah anak-anaknya karena caranya yang berbeda dengan cara yang diterapkan guru jaman dulu ketika orang tua sekolah. Ada yang tidak setuju ketika anak-anaknya diajak guru keluar kelas untuk memetik berbagai jenis daun, atau bercerita di bawah pohon rindang, atau memanen ikan sambil menghitung dan kemudian mengolah hasil tangkapannya. "Kok anak-anak hanya bermain saja, tidak belajar?" Begitu biasanya pertanyaan beberapa orang tua.

Banyak orang tua yang masih beranggapan bahwa belajar itu seharusnya hanya di ruang kelas, di mana anak-anak duduk tekun mendengarkan gurunya menjelaskan setiap mata pelajaran. Bahkan untuk pendalamannya, anak seharusnya diberi pekerjaan rumah (PR). Ternyata, banyak juga guru yang berpendapat demikian. Apakah benar bahwa seperti itulah metode pembelajaran yang baik? Bagaimanakah metode pembelajaran yang baik itu?

Metode pembelajaran yang baik seharusnya selaras dan mendukung pencapaian tujuan kurikulum yang baik. Di Indonesia, kurikulum sekolah harus selaras dengan Undang-Undang Sisdiknas pasal 3 nomor 20 tahun 2003, yang pada intinya adalah mengamanat kepada setiap sekolah untuk melaksanakan pendidikan secara holistik dengan cara mengembangkan seluruh potensi peserta didik. Dengan kata lain, metode pembelajaran yang baik bukan hanya mengembangkan aspek kognitif atau akademik saja, tetapi juga harus mampu membentuk manusia utuh (whole person) yang cakap dalam menghadapi dunia yang penuh tantangan dan cepat berubah, serta mempunyai kesadaran spiritual bahwa dirinya adalah bagian dari keseluruhan (the person within a whole) (Megawangi, Latifah, Dina, 2004).

Telah disebutkan bahwa pendidikan di sekolah seharusnya bertujuan untuk membangun manusia holistik. Agar tujuan itu tercapai, maka prinsip pendidikan harus mengacu kepada prinsip-prinsip pembelajaran yang dapat mengarahkan proses pembelajaran secara efektif. Berdasarkan hasil studi pustaka dari berbagai sumber, maka dapat disimpulkan bahwa ada tiga prinsip pembelajaran efektif bagi pendidikan terutama di tingkat dasar (Megawangi, dkk., 2004) :

a. Pembelajaran memerlukan pastisipasi aktif para siswa (belajar aktif). Motivasi belajar akan meningkat kalau siswa terlibat aktif (mempraktekan) dalam mempelajari hal-hal yang konkrit, bermakna, dan relevan dalam konteks kehidupannya. 
b. Setiap anak belajar dengan cara dan kecepatan yang berbeda

c. Anak-anak dapat belajar dengan efektif ketika mereka dalam suasana kelas yang kondusif (conducive learning community), yaitu suasana yang memberikan rasa aman dan penghargaan, tanpa ancaman, dan memberikan semangat.

Ketiga prinsip pembelajaran tersebut didukung oleh beberapa hasil riset otak yang mempunyai implikasi terhadap pendidikan. National Research Council (1999) dalam Megawangi, dkk. (2004) mengumpulkan dan mengkompilasikan berbagai hasil riset otak yang harus menjadi acuan bagi para pendidik agar proses pendidikan dapat berjalan dengan efektif. Beberapa hasil riset tersebut adalah :

a. Proses belajar melibatkan seluruh dimensi manusia (tubuh, pikiran, dan emosi)

b. Faktor emosi sangat berperan dalam mempengaruhi sistem limbik otak yang dikenal sebagai otak emosi. Sistem limbik ini berperan dalam memfilter segala macam persepsi yang masuk. Apabila persepsi yang masuk berupa ancaman, ketakutan, kesedihan, maka bagian batang otak yang merupakan otak reptil (binatang) akan lebih berperan sehingga seseorang akan berada dalam modus bertahan atau menyelamatkan diri. Suasana di kelas tradisional yang kaku akan menurunkan fungsi otak menuju batang otak, sehingga anak tidak bisa berpikir efektif. Sedangkan dalam kondisi yang menyenangkan, aman, dan nyaman akan mengaktifkan bagian neocortex (otak berpikir), sehingga dapat mengoptimalkan proses belajar dan meningkatkan kepercayaan diri anak.

c. Informasi yang menarik dan bermakna akan disimpan lebih lama dalam memori, sedangkan informasi yang membosankan dan tidak relevan, akan mudah dilupakan. d. Kaitan erat antara aspek fisiologi, emosi dan daya ingat mempunyai implikasi penting bagi proses belajar, yaitu : suasana belajar yang menyenangkan, melibatkan seluruh aspek sensori manusia (panca-indera), relevan atau kontekstual, dan yang terpenting, proses belajar harus memberikan rasa kebahagiaan.

e. Manusia akan lebih mudah mengerti kalau terlibat secara langsung dalam mengerjakannya, atau dengan ingatan spatial (bentuk atau gambar).

Hasil studi Lewis dan Schaos (1996) dalam Megawangi, dkk. (2004) menunjukkan bahwa suasana kelas yang kondusif akan mempunyai dampak yang positif motivasi dan kemampuan anak. Adapun ciri-ciri kelas yang kondusif sehingga membuat para siswa memiliki motivasi belajar yang tinggi, berani mencoba (risk-taker), dan menjadi pembelajar sejati adalah sebagai berikut:

a. Adanya pendidikan karakter secara eksplisit, sehingga akan terbentuk sikap anak yang saling menghormati, saling menghargai, bertanggung jawab, dan sebagainya.

b. Adanya peraturan dan kode etik yang dibuat dengan kesepakatan seluruh kelas dan dipatuhi dengan baik.

c. Hubungan antar siswa saling mendukung, tidak terlihat adanya persaingan antar siswa yang tidak sehat.

d. Adanya rasa saling percaya dan saling menghormati antar siswa dan guru. Guru menghormati dan memperlakukan siswa dengan baik.

e. Guru berusaha mengenal siswa secara pribadi dan mengetahui keunikan masing-masing siswa.

f. Guru bertindak sebagai fasilitator yang memberikan peluang berinisiatif bagi siswa dan memotivasi siswa untuk tertarik pada materi pelajaran. 
g. Guru selalu siap untuk merencanakan kegiatan harian yang dapat menstimulasi seluruh dimensi perkembangan siswa.

h. Setiap siswa merasa bahwa keberadaannya sebagai anggota kelas diterima dan dihargai.

i. Setiap siswa merasa terlibat dalam pengambilan keputusan, dan para siswa berpartisipasi aktif dalam proses belajar.

j. Adanya kesempatan bagi para siswa untuk belajar dalam kelompok sehingga siswa dapat belajar bagaimana berinteraksi secara positif.

k. Iklim belajar yang menyenangkan; tidak ada tekanan dan beban yang berlebihan, tetapi siswa-siswa tercelup dalam kegiatan belajar secara intensif.

1. Iklim belajar yang memberikan peluang bagi siswa untuk membuat kesalahan sebagai bagian alami dalam proses belajar (tidak memvonis siswa yang belum menguasai pelajaran), sehingga para siswa bisa menjadi risk-taker, dan mempunyai motivasi untuk mempelajari hal-hal yang baru dan sulit.

\section{Perumusan Masalah.}

Desa Randu, Kec. Subah, merupakan daerah penopang wilayah Kabupaten Batang. Desa Randu merupakan salah Ranting Muhammadiyah yang cukup maju di Kec. Subah, namun sebagian besar perkembangan sekolah di Kec. Subah belum maju.

Kecamatan Subah harus ditingkatkan kemampuan gurunya dalam profesinya; dengan meningkatkan mutu guru-guru dalam pembelajaran diharapkan, hasil pembelajaran dapat menyamai secara nasional di wilayah lain sehingga dapat menunjang program peningkatan hasil UAS maupun UAN, guru tambah berkualitas dalam mengajarnya, variatif dalam penggunaan metode, kompetensi mengajar semakin meningkat, membongkar paradigm introvert menjadi ekstrovert, lebih siap secara mental dan administratif (RPP).

Perumusan masalah pada kegiatan ini yaitu dengan pelatihan untuk:

a. Peningkatan mutu pembelajaran di kelas di sekolah swasta (Muhammadiyah).

b. Pengenalan dan penguasaan strategi pembelajaran PAIKEM

c. Penerapan strategi sistem PAIKEM (dilatihkan pada micro teaching).

d. Meningkatkan mental dari introvert menjadi ekstrovert terhadap hal-hal/ strategi-strategi baru.

Dengan demikian tujuan pengabdian ini adalah:

a. Dapat meningkatkan mutu pembelajaran di kelas di sekolah swasta (Muhammadiyah).

b. Melakukan pengenalan dan penguasaan strategi pembelajaran PAIKEM

c Melakukan penerapan strategi sistem PAIKEM (dilatihkan pada micro teaching).

d. Meningkatkan mental dari introvert menjadi ekstrovert terhadap hal-hal/ strategi-strategi baru.

\section{Tinjaun Pustaka}

Strategi adalah unsur penting pembelajaran, namun penguasaan strategi mayoritas guru masih sebatas ceramah yang bersifat monoton dan pasif, siswa sebagai obyek dan tidak terlibat, kegiatan pembelajaran didominasi oleh guru. Padahal pembelajaran selalu melibatkan dua pihak, yaitu guru dan siswa, sehingga pembelajaran yang baik adalah pembelajaran yang melibatkan kedua belah pihak, dan inilah yang disebut dengan metode/strategi pembelajaran partisipatif.

Hal ini dapat terjadi disebabkan:

a. Guru lebih menyukai yang konvensional. Sehingga bila kebijakan kurikulum baru menghendaki berubah dari yang lama maka masih perlu waktu untuk sosialisasi 
dan pengawasan yang tertib untuk perbaikan-perbaikan. Sosialisai strategi alternative tidak berhenti pada teori-teori strategi namun perlu contoh kongkrit dari para penatar, tutor strategi alternatif tersebut, karena sampai saat ini belum ada latihan sampai praktek menggunakan strategi Partisipatif secara nyata di kelas micro teaching.

b. Guru kurang menguasi untuk menerapkan strategi alternative (metode partisipatif).

Kurikulum satuan pendidikan yang menjadi program Pendidikan Nasional oleh Pemerintah menuntut peningkatan kualitas pembelajaran bagi guru. Sementara itu program peningkatan mutu pembelajaran guru belum diiringi usaha peningkatan dari pemerintah dengan pelatihan (workshop) tentang pembelajaran strategi partisipatif secara merata pada sekolah-sekolah swasta dibawah naungan yayasan swasta. Hal ini terjadi terutama guru-guru sekolah swasta seperti sekolah Menengah Pertama Darul Hijrah.

Model pembelajaran alternative (PAIKEM) yang selaras dengan filosofi KTSP dan CTL siswa dikondisikan aktif dan partisipatif maka menjadi masalah apabila guru masih bertahan pada cara mengajar yang didominasi dengan metode ceramah, sebagaimana yang dikatakan oleh Melsiberman dalam Active Learning, 101 Strategies to Teach Any Subeject yang mengutip kata bijak Konfiusius seorang filosof Cina: apa yang saya dengar saya lupa, apa yang saya lihat saya ingat, apa yang saya kerjakan saya paham (1996: 23).

Secara implisit Melsilberman ingin menunjukkan bahwa belajar lebih bermakna dan bermanfaat apabila siswa menggunakan semua indranya, sekaligus berfikir dan mengolah informasi dan ditambah dengan mengerjakan sesuatu. Pembelajaran aktif digunakan dengan alasan bahwa siswa memiliki ragam style, antara lain: auditive, visual, kinestetik, dapat tercover (Mahasri, 2008: 4).

Dengan demikian bahwa pembelajaran konvensional sudah tidak cocok lagi untuk penerapan Kurikulum Terpadu Satuan Pendidikan (KTSP) namun satu sisi guru belum banyak mengenal dan dikenalkan secara aplikatif, tetapi masih pada tahapan teori-teori alternative (PAIKEM) baik pada sosialisasi pembelajaran aktif atau seminarseminar yang sejenis. Dengan demikian latihan dan mempratekkan metode-metode baru yaitu strategi-strategi pembelajaran aktif sangat dibutuhkan oleh para guru-guru dan para tutor-tutor PLPG atau para supervisor.

Dalam rangka untuk memenuhi kebutuhan tersebut perlu diadakan pelatihan dan praktek mengajar dalam Micro Teaching yang dikondisikan active learning bagi guru khususnya guru-guru swasta (Muhammadiyah) dengan materi-materi yang di desain oleh dan untuk guru dalam PBM.

\section{Tujuan dan Manfaat}

Setelah pelatihan Pembelajaran PAIKEM bagi guru di sekolah Muhammadiyah, diharapkan ada manfaat yang akan diperoleh yakni:

a. Manfaat Jangka Pendek

Dalam jangka pendek akan terjadi peningkatan mutu pembelajaran bagi guru swasta di lingkungan Muhammadiyah serta memiliki dan menguasai strategi pembelajaran yang variatif.

b. Manfaat Jangka Panjang

Manfaat jangka panjang yang diharapkan adalah untuk menunjang keberhasilan sekolah dalam penyelenggaraan UAS dan untuk menyetaraan mutu pembelajaran secara nasional yaitu keberhasilan UAN. 


\section{METODE PELAKSANAAN}

Metode yang akan digunakan untuk merealisasi program ini adalah berbentuk pelatihan mendesain pembelajaran PAIKEM (Pembelajaran aktif, inovatif, kreatif, efektif dan menyenangkan) bagi guru Muhammadiyah di Desa Randu, Kec. Subah Kab. Batang.

Secara umum tujuan kegiatan ini adalah untuk membekali guru-guru swasta (Muhammadiyah) di Desa Randu, Kec. Subah Kab. Batang dengan pengenalan dan penerapan pembelajaran PAIKEM agar dapat diterapkan disekolah mereka, sehingga mereka menjadi guru profesional sebelum mengadakan pembelajaran tentunya telah mempersiapkan pembelajaran secara strategis agar dapat menumbuhkan motivasi dan lebih memahamkan siswa secara sederhana dalam komunikasi pembelajaran.

\section{HASIL DAN PEMBAHASAN}

Pelatihan Pembelajaran PAIKEM diselenggarakan atas permintaan guru-guru Muhammadiyah di Desa Randu. Secara umum tujuan kegiatan ini adalah untuk membekali guru-guru swasta (Muhammadiyah) di Desa Randu, Kec. Subah Kab. Batang dengan pengenalan dan penerapan pembelajaran PAIKEM agar dapat diterapkan disekolah mereka, sehingga mereka menjadi guru profesional.

Pelatihan ini lebih ditekankan kepada guru-guru sekolah swasta (Muhammadiyah) karena selama ini kebijakan pendidikan yang dilakukan pemerintah pusat sampai daerah bersifat insidental dan belum tersosialisasi secara merata dengan menempatkan sekolah negeri sebagai prioritas, dan menomer duakan sekolah swasta, sehingga menjadi kurang tersentuh dari kebijakan pemerintah. Padahal semua sekolah, baik negeri ataupun swasta (Muhammadiyah) sama-sama bertugas mencerdaskan kehidupan anak bangsa. Sehingga dengan adanya pelatihan ini diharapkan program atau lembaga pendidikan menjadi berkembang, eksis berkelanjutan, real dan implementatif.

Selain itu guru-guru swasta (Muhammadiyah) karena guru-guru swasta tidak/belum menjadi prioritas utama salama guru negeri belum tercukupi, padahal bila dilihat rasio sekolah, murid dan guru relative lebih banyak sekolah swasta, bila dilihat beban mengajar di sekolah negeri dan standar UAN sebagai acuan semua sekolah swasta, ini menjadi beban berat, mengingat dilihat dari ketersediaan fasilitas dan senioritas guru jauh lebih siap sekolah negeri akan tetapi tuntutan secara nasional sama, maka pantaslah bila pilihan mitra pada guru sekolah swasta (Muhammadiyah).

Pelatihan pembelajaran PAIKEM dilaksanakan pada hari Minggu, 9 Januari 2011 dengan difasilitatori oleh Drs. Zaenal Abidin, M.Pd., Drs. Moh. Yusron, M.Ag., Winarno, S.Ag. Acara tersebut dimulai pada jam 08.00 sampai 09.00, yaitu berupa kegiatan pembukaan. Dalam pembukaan tersebut disampaikan sambutan dan sekaligus pengarahan tentang pentingnya pelatihan pembelajaran PAIKEM, oleh ketua pelaksana kegiatan, yaitu Bapak Ghofur, S,Th.I.

Pada pukul 09.00 sampai dengan 09.45 dilanjutkan kegiatan orientasi pelatihan dan perkenalan. Yang mana dalam kegiatan orientasi tersebut difasilitasi oleh Drs. Zaenal Abidin, M.Pd. dalam presentasinya beliau menjelaskan kelemahan metode pengajaran secara ceramah, menurutnya kemampuan siswa dalam menyimak terbatas (menurut riset pd 10-15 menit pertama mampu menyerap $70 \%$ informasi, lebih dari itu hanya $20 \%$ yg diserap).

Ketika mendengarkan ceramah siswa mudah sekali terganggu (karena manusia biasanya lebih terfokus pada sesuatu yg terlihat mata, visual, dari pada yg terdengar, audio. Ketika sesuatu terlintas di mata maka berenti mendengar. 
Namun begitu bukan berarti metode ceramah tidak layak untuk dipergunakan. Metode ceramah masih bisa dilakukan apabila dalam kondisi untuk menyampaikan informasi baru, untuk kelas besar,untuk prngajaran kognisi tingkat rendah.

Perkenalan fasilitator dan juga peserta di fasilitasi oleh Winarno, dalam perkenalan tersebut semua peserta dimohon untuk mengenalkan dirinya dengan kategori nama, asal/alatmanya serta hal yang tidak disenangi.

Pukul 09.45 sampai dengan 10.00 dilanjutkan break yang difasilitasi oleh panitia. Kemudian pukul 10.00 sampai dengan 10.45 dilanjutkan pelatihan materi 1 , yakni mengenalkan strategi pembelajaran ICM (Index Card Match) yang difasilitasi oleh Drs. Zaenal Abidin, M.Pd. Dalam strategi ini fasilitator menerangkan langkahlangkah dalam penggunaan strategi ICM.

Pukul 10.45 sampai dengan 11.45 dilanjutkan dengan materi 2, yakni mengenalkan strategi pembelajaran Snow Balling yang difasilitasi oleh Drs. Moh. Yusron, M.Ag. Dalam strategi ini fasilitator menerangkan langkah-langkah dalam penggunaan strategi Snow Balling.

Pukul 11.15 sampai dengan 12.30 dilanjutkan dengan materi ke-3, yakni mengenalkan strategi pembelajaran CS (Card Short) yang difasilitasi oleh Winarno. Dalam strategi ini fasilitator menerangkan langkah-langkah dalam penggunaan strategi Card Short.

Pukul 12.30 sampai dengan 13.00 diilanjutkan dengan break yang difasilitasi oleh panitia. Kemudian Pukul 13.00 sampai dengan 13.45 dilanjutkan dengan materi ke4, yakni mengenalkan strategi pembelajaran GJ (Galeri Jawaban) yang difasilitasi oleh Drs. Moh. Yusron, M.Ag. Dalam strategi ini fasilitator menerangkan langkah-langkah dalam penggunaan strategi GJ (Galeri Jawaban).
Pukul 13.45 sampai dengan 14.15 dilanjutkan dengan materi ke-5, yakni mengenalkan strategi pembelajaran ToF (True or False) yang difasilitasi oleh Winarno. Dalam strategi ini fasilitator menerangkan langkah-langkah dalam penggunaan strategi ToF (True or False).

Pukul 14.15 sampai dengan 15.30 dilanjutkan dengan materi ke-6, yakni mengenalkan strategi pembelajaran QSH (Question Student Here) yang difasilitasi oleh Drs. Zaenal Abidin, M.Pd. Dalam strategi ini fasilitator menerangkan langkah-langkah dalam penggunaan strategi QSH (Question Student Here).

Pukul 15.30 sampai dengan 16.00 diilanjutkan dengan break yang difasilitasi oleh panitia. Kemudian Pukul 16.00 sampai dengan 16.30 dilanjutkan dengan penutupan kegiatan yang difasilitasi oleh panitia.

Sebelum acara penutupan setiap perserta diminta untuk menyampaikan kesan dan pesan dalam pelatihan tersebut. Alhamdulillah $100 \%$ peserta merasa senang dengan diadakannya pelatihan pembelajaran PAIKEM, serta memperoleh strategi pembelajaran yang baru, dikarenakan selama ini mereka lebih banyak menggunakan strategi ceramah.

\section{SIMPULAN DAN SARAN}

\section{Simpulan}

a. Metode yang akan digunakan untuk merealisasi program ini adalah berbentuk pelatihan mendesain pembelajaran PAIKEM (Pembelajaran aktif, inovatif, kreatif, efektif dan menyenangkan) bagi guru Muhammadiyah di Desa Randu, Kec. Subah Kab. Batang.

b. Peserta merasa senang dengan diadakannya pelatihan pembelajaran PAIKEM, serta memperoleh strategi pembelajaran yang baru, dikarenakan 


\section{Saran}

selama ini mereka lebih banyak menggunakan strategi ceramah

Bagi guru-guru hendaknya dapat menggunakan strategi yang telah diberikan dalam pelatihan sehingga memiliki manfaat bagi kelangsungan pendidikan.

\section{PERSANTUNAN}

Kegiatan penelitian tidak akan berhasil kalau tidak mendapatkan dukungan dari beberapa pihak yang terlibat dalam kegiatan ini, maka ucapan terima kasih kami haturkan kepada:

1. Dr. Harun Joko Prayitno, M.Hum., selaku Ketua Lembaga Penelitian dan Pengabdian
Masyarakat UMS atas kesempatan yang diberikan kepada kami, baik melalui dana maupun saran.

2. Drs. M.A. Fattah S, M.Ag., selaku Dekan Fakultas Agama Islam Universitas Muhammadiyah Surakarta, yang dengan penuh ketulusan dan semangat telah memberikan dorongan moril dan materiil kepada kami.

3. Kepala Sekolah Sekolah Dasar dan guruguru Muhammadiyah di Desa Randu Kec. Subah, Kab. Batang yang telah ikut serta dalam menyukseskan pelatihan ini.

\section{DAFTAR PUSTAKA}

Abidin, Zaenal 2004. Strategi Pembelajaran di Perguruan Tinggi Optimalisasi Kinerja Dosen dalam Pembelajaran Aktif di Fakultas Agama Islam Universitas Muhammadiyah Surakarta. LPPM: UMS

Departemen Agama RI Direktorat Jendral Kelembagaan Agama Islam. 2003. Memahami Paradigma Baru Pendidikan Sosial dalam Undang-Undang SISDIKNAS. Jakarta: Ditjen Kelembagaan Agama Islam Depag.

Graham Gibbs and Martin Coffey, 2004. The Impact of Training of University Teachers on their Theaching Skills, their approach to teaching and the approacha ta learning of theis Students. New Delhi : The Isntitute for Learning ang Teaching in Higher Education and SAGE Publications Vol.5 (1).

Hasbullah. 1999. Kapita Selekta Pendidikan Islam. Jakarta: Raja Grafindo Persada.

Hasbullah. 2007. Otonomi Pendidikan. Jakarta: Raja Grafindo Persada.

Lie, Anita, 2002. Cooperative Learning, Mempratekkan Cooperative Learning di Ruangruang Kelas. Jakarta: Grasindo.

Megawangi, R; M. Latifah; W.F. Dina. 2004. Pendidikan Holistik : Aplikasi KBK untuk Menciptakan Lifelong Learners. Indonesia Heritage Foundation.

Mahasri dkk, 2008. Model Pembinaan Guru PAI melalui Insevice Training Desain Pembelajaran dalam Varia Pendidikan Vol. 20, No. 1 ISSN. 0852-0976.

Nata, Abuddin. 2003. Filsafat Pendidikan Islam. Jakarta: Logos Wacana Ilmu.

Rooijakkers. 1986. Innovative Teaching Strategies. Scottdale: Gorsuch Scorisbrick Publisher.

Silberman, M. 1996. Active Learning, 101 Strategis to Teach by Subject, Toronto: Allyn Bacon. 